
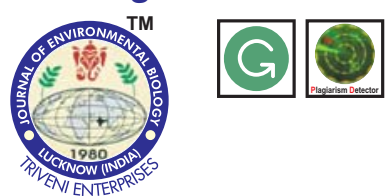

\title{
Standardization of stocking density for maximizing biomass production of Pangasius pangasius in pond cage aquaculture
}

Authors Info

S. N. Datta ${ }^{1 *}$, A. Dhawan", S. Kumar ${ }^{1}$, A. Singh ${ }^{2}$ and P. Parida ${ }^{1}$

'Department of Fisheries Resource Management, College of Fisheries, Guru Angad Dev Veterinary and Animal Sciences University, Ludhiana-141 004, India

${ }^{2}$ Department of Harvest and PostHarvest Technology, College of Fisheries, Guru Angad Dev Veterinary and Animal Sciences University,

Ludhiana-141 004, India

*Corresponding Author Email : surjya30740@gmail.com

Key words

Cage aquaculture, Condition factor,

Feed conversion ratio,

Pangasius pangasius, Productivity, Stocking density

Publication Info

Paper received : 08.05.2015

Revised received : 06.02.2016

Re-revised received : 25.06.2016

Accepted:13.07.2016

\section{Abstract}

Aim : Pangasius pangasius, a species of freshwater shark catfish native to Mekong River is highly resistant to crowding and low oxygen therefore, can be a suitable species for cage aquaculture. The objective of the present study was to standardize the stocking density of catfish $P$. pangasius in pond cage aquaculture for maximizing biomass per unit water area.

Methodology : A comparative study was conducted in fish cages $(2.0 \mathrm{~m} \times 2.0 \mathrm{~m} \times 1.0 \mathrm{~m})$ installed in earthen pond of $600 \mathrm{~m}^{-2}$ area and depth of $2.0 \mathrm{~m}$. Stocking density of P. pangasius fingerlings was maintained @ 15 $\mathrm{m}^{-3}\left(\mathrm{C}_{1}\right), 20 \mathrm{~m}^{-3}\left(\mathrm{C}_{2}\right), 25 \mathrm{~m}^{-3}\left(\mathrm{C}_{3}\right)$ and $30 \mathrm{~m}^{-3}\left(\mathrm{C}_{4}\right)$, respectively. Fish seed was procured from, Kolkata, West Bengal. The experiment was conducted for 120 days. Fish (in cages) were fed with formulated diets $(30.0 \%$ crude protein on dry weight basis) @ 3\% body weight twice a day. Physico-chemical parameters of water and growth parameters were calculated.

Results : Maximum biomass was produced in $\mathrm{C}_{3}$ which was $60.14 \%$, $22.72 \%$ and $12.21 \%$ higher than $\mathrm{C}_{1}, \mathrm{C}_{2}$ and $\mathrm{C}_{4}$, respectively, with cent percent survivability in all the cages. Better feed conversion ratio was noted in $\mathrm{C}_{3}(1.541)$ as compared to $\mathrm{C}_{1}(1.825), \mathrm{C}_{2}(1.645)$ and $\mathrm{C}_{4}$ (1.956), indicating higher the stocking density better feed conversion ratio up to stocking density of $25 \mathrm{~m}^{-3}$, and afterwards (@ $30 \mathrm{~m}^{-3}$ ) food conversion efficiency decreased. The experimental fish recorded the value of exponent ' $b$ ' in the range of 2.868 to 3.063 revealing both negative, as well as positive allometric growth pattern and condition factor ' $\mathrm{K}$ ' of all experimental fish was above 1.0 (1.344 - 1.825) indicating robustness or well-being of experimented fish.

Interpretation : The appreciable growth rate exhibited by fish during rearing period indicated that the species is suitable for cage culture at higher stocking density as food fish to meet the increasing nutritional demand.

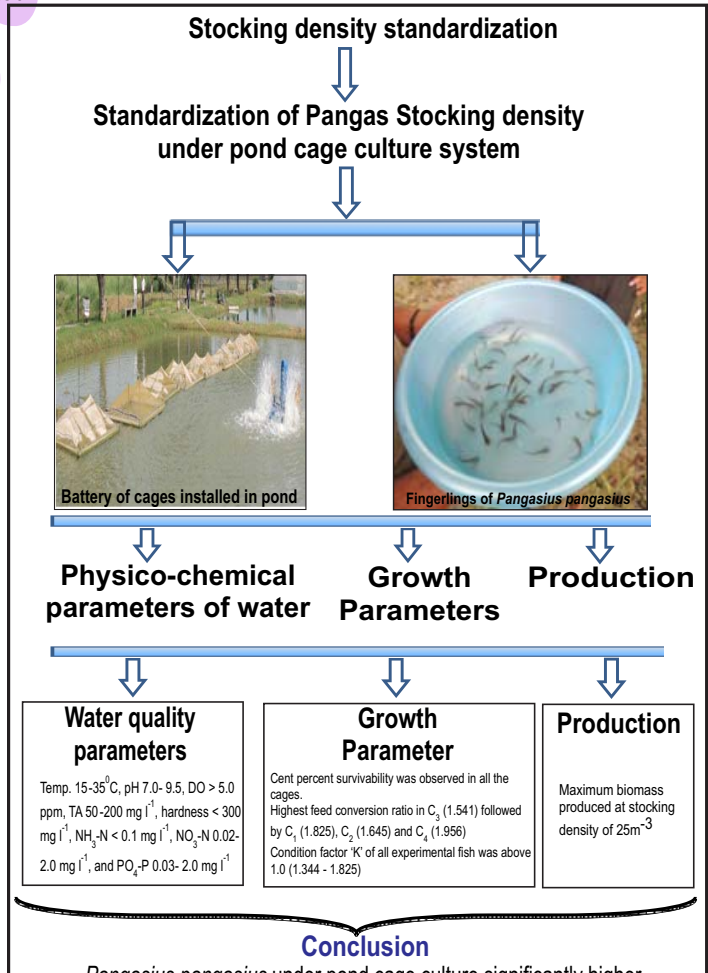
biomass was produced at stocking density of $25 \mathrm{~m}^{-3}$ with $30.0 \%$ crude protein feed
Pangasius pangasius under pond cage culture significantly higher 


\section{Introduction}

Population growth in developing nations is a leading cause for major changes in demand and supply for animal protein, from both livestock and fish (Delgado et al., 2003). In last 20 years cage aquaculture has grown rapidly and the growth is still occurring in response to increasing demand of aquatic products from developed and developing nations (Halwart et al., 2007). Pond cage aquaculture can play a major role in meeting this demand in areas away from coast line. In pond cage culture, fish in cages are fed with high-protein diet, while fish in pond depend on leftover feed and excreta of fish reared in cages (Yi and Lin, 2001). Pond cage aquaculture with high stocking density provides higher production, if crowding resistant species are used in cages (Datta et al., 2014). Pangasius, a well-known catfish is one of the major fish species in the Mekong River and regarded as one of the largest and most important inland fishery resource in the world. It is now considered as the $3^{\text {rd }}$ most important freshwater fish group within the aquaculture sector. It is considered as economically important food fish because of its fast growth, versatile feeding habit and hardiness. Pangasius is considered as low risk aquaculture species since it cannot reproduce naturally, fingerlings are produced by local hatcheries through induced spawning. Different species of Pangasius are highly resistant to stocking density (Hung et al., 2001; Chattopadhyay et al., 2002). Pangasius pangasius (Hamilton, 1822) is native to fresh and brackish waters of Bangladesh, India, Myanmar and Pakistan (Pal, 2010). Other species of Pangasius are used for commercial aquaculture but $P$. pangasius is cultured at limited scale (Pilay and Kutty, 2005) so the standardization of culture practices become necessary for economic benefits. This paper deals with the objective of standardizing the stocking density of $P$. pangasius in pond cage aquaculture for maximizing biomass per unit area.

\section{Materials and Methods}

The study was conducted at the Fish Farm of College of Fisheries, Guru Angad Dev Veterinary and Animal Sciences University, Ludhiana (Punjab), India $\left(30.54^{\circ} \mathrm{N}\right.$ latitude, $75.48^{\circ} \mathrm{E}$ longitude and an altitude of $247 \mathrm{~m}$ above mean sea level). The experiment (in triplicate) was conducted in fish cages $(2.0 \mathrm{~m} \times 2.0$ $\mathrm{m} \times 1.0 \mathrm{~m}$ cage bag size and $3 \mathrm{~mm}$ knot-less HDPE) installed in earthen pond of $600 \mathrm{~m}^{-2}$ area and depth of $2.0 \mathrm{~m}$. Stocking density of $P$. pangasius fingerlings was maintained @ $15 \mathrm{~m}^{-3}$ (total 60 number) $\left(C_{1}\right), 20 \mathrm{~m}^{-3}$ (total 80 number) $\left(C_{2}\right), 25 \mathrm{~m}^{-3}$ (total 100 number) $\left(\mathrm{C}_{3}\right)$ and $30 \mathrm{~m}^{-3}$ (total 120 number) $\left(\mathrm{C}_{4}\right)$, respectively. $P$. pangasius (average length $2.93 \pm 0.2 \mathrm{~cm}$ and weight $0.25 \pm 0.05 \mathrm{~g}$ ) collected from fish seed hatchery, Kolkata, West Bengal. The experiment was conducted for 120 days.

Formulated diets : Supplementary diet $(30.0 \%$ crude protein on dry weight basis) was formulated using agro-industrial byproducts i.e. rice bran (30\%), de-oiled ground nut (30\%), de-oiled soybean $(25 \%)$, fish meal $(13 \%)$ and vitamin - mineral mixture (2\%). For preparation of diet, all dry feed ingredients were first grounded to a small particle size in a laboratory electric grinder and sieved through an approximately $250 \mu \mathrm{m}$ sieve. Ingredients were thoroughly mixed in a commercial food mixer for $15 \mathrm{~min}$. Stiff dough was prepared by adding water. The wet mixture was steamed for $5 \mathrm{~min}$. and the diets were extruded with the help of a pelletizer of $2.0 \mathrm{~mm}$ in diameter. The pelleted diets were dried overnight at $55^{\circ} \mathrm{C}$, afterwards were broken up and sieved into appropriate pellet sizes. Proximate composition of feed ingredients and formulated diets (Table 1) was determined as per the standard methods of AOAC (2005).

Feeding of fish : Fish (in cages) were fed with formulated diets @ $3 \%$ of body weight in total (two meals of $1.5 \%$ body weight) twice a day $(9.00$ am and $5.00 \mathrm{pm})$. Check trays were maintained in each cage to calculate the amount of feed provided and amount of uneaten feed in each treatment for accurate calculation of Feed Conversion Ratio (FCR) and Protein Efficiency Ratio (PER). The feed quantity was regulated based on the fortnightly sampling of 30 fish each from all the replications of each treatment. The following formulae were used to calculate FCR and PER:

$\mathrm{FCR}=$ Weight of feed given $(\mathrm{g}) /$ Fish weight gain $(\mathrm{g})$

PER = Fish weight gain (g)/Protein intake (g).

Water analysis : Physico-chemical parameters of water samples including water temperature, $\mathrm{pH}$, dissolved oxygen, total alkalinity, hardness, ammonia-nitrogen $\left(\mathrm{NH}_{3}-\mathrm{N}\right)$, nitrate-nitrogen $\left(\mathrm{NO}_{3}-\mathrm{N}\right)$, nitrite-nitrogen $\left(\mathrm{NO}_{2}-\mathrm{N}\right)$ and phosphate-phosphorous $\left(\mathrm{PO}_{4}-\mathrm{P}\right)$ were measured at weekly interval from the four corners of the experimental pond following standard methods (APHA, 2012).

Growth analysis : Random sampling of 30 fish from each of the replicate of each treatment were measured for total length (TL) and total weight (TW) at fortnightly interval basis to analyze the

Table 1 : Proximate composition (\%) of feed ingredients and experimental diet

\begin{tabular}{|c|c|c|c|c|c|c|}
\hline Ingredients & Moisture & Crude protein & Ether extract & Crude fiber & Ash & Nitrogen free extract \\
\hline Rice bran & 14.20 & 16.73 & 1.4 & 8.89 & 12.08 & 45.80 \\
\hline Groundnut cake & 13.50 & 41.59 & 2.90 & 7.81 & 4.30 & 29.90 \\
\hline Soybean meal & 12.10 & 42.50 & 3.60 & 6.80 & 5.90 & 29.10 \\
\hline Fish meal & 14.65 & 48.35 & 3.0 & 3.10 & 21.75 & 9.15 \\
\hline Experimental diet & 13.20 & 30.0 & 2.75 & 5.52 & 9.65 & 38.87 \\
\hline
\end{tabular}


growth of fish. The following parameters were calculated to determine the growth response of the fish to the diets:

Daily Weight Gain (DWG) (g/day) $=W_{-}-W_{i}(g) /$ Culture period (days) Relative Growth Rate $(R G R)(\%)=\left(W_{f}-W_{i}\right) \times 100 / W_{f}$

Where $\mathrm{W}_{\mathrm{f}}=$ Final average weight at end of experiment and $\mathrm{Wi}=$ Initial average weight at beginning of experiment.

Specific growth rate $(S G R)=\left[\log _{e}(\right.$ Final weight in gram $)-\log _{e}$ (Initial weight in gram)]X100/Culture days

Survival Rate $(\%)=$ Number of fish that survived X $100 /$ Number of fish stocked

Length-weight relationship : The length-weight (logtransformed) relationships were determined by linear regression analysis and scatter diagrams of length and weight. The lengthweight relationship of the experimented fish is worked out as per Le Cren (1951).

$W=a L^{b}$

where, $W$ is weight of fish $(\mathrm{g}), \mathrm{L}$ is total length $(\mathrm{cm})$, ' $a$ ' is the regression intercept and ' $b$ ' is the regression slope.

The logarithmic transformation of the above formula is-

$\log W=\log a+b \log L$

Fulton's condition factor $(\mathrm{K})$ : Fulton's condition factor $(\mathrm{K})$ was calculated according to Htun-Han (1978) equation as per formula given below:

\section{$\mathrm{K}=\mathrm{W} \times 100 / \mathrm{L}^{3}$}

Where, $\mathrm{W}=$ weight of fish $(\mathrm{g}), \mathrm{L}=$ Length of fish $(\mathrm{cm})$.
Statistical analysis : The analysis of covariance was performed to determine variation in ' $b$ ' values following the method of Snedecor and Cochran (1967). The statistical significance of Isometric exponent (b) was analyzed by a function: $t s=(b-3) / S b$ (Sokal and Rohlf, 1987) where, ts is t- test value; ' $b$ ' is the slope and $\mathrm{Sb}$ is the standard error of ' $b$ ' and comparison between obtained values of t-test and the respective critical values determined that ' $b$ ' values statistically significant and their inclusion in the isometric range $(b=3)$ or allometric range (negative allometric; $b<3$ ). Statistical software SPSS 16 and PAST Ver. 1.8 was used in this study.

\section{Results and Discussion}

All mean values of water quality parameters viz. temperature, $\mathrm{pH}$, dissolved oxygen (DO), total alkalinity (TA), hardness, $\mathrm{NH}_{3}-\mathrm{N}$, $\mathrm{NO}_{3}-\mathrm{N}$, and $\mathrm{PO}_{4}-\mathrm{P}$ were within the acceptable range ( Temp. 15$35^{\circ} \mathrm{C}, \mathrm{pH} 7.0-9.5, \mathrm{DO}>5.0 \mathrm{ppm}, \mathrm{TA} 50-200 \mathrm{mg} \mathrm{l}^{-1}$, hardness $<300$ $\mathrm{mgl}^{-1}, \mathrm{NH}_{3}-\mathrm{N}<0.1 \mathrm{mg} \mathrm{l}^{-1}, \mathrm{NO}_{3}-\mathrm{N} 0.02-2.0 \mathrm{mg} \mathrm{l}^{-1}$, and $\mathrm{PO}_{4}-\mathrm{P} 0.03-$ $2.0 \mathrm{mg} \mathrm{I}^{-1}$ ) as suggested by Bhatnagar and Devi, (2013) for general aquaculture in pond (Table 2). A cent percent survival was observed in all the cages indicating that survival rate remained unaffected upto stocking density of $30 \mathrm{~m}^{-3}$. Similar results were observed in Pangasius bocourti with survival rate higher than $90 \%$ in stocking densities $12,25,50,100$, and 200 fish $\mathrm{m}^{-3}$ (Jiwyam, 2011). Constant survival rate with changing the stocking density was also observed in Pangasius sutchi reared in cages by Rahman et al. (2006). Thus it can be said that $P$. pangasius can sustain the crowding environment in fish cages. Maximum weight gain was recorded in $\mathrm{C}_{3}$ followed by $\mathrm{C}_{4}, \mathrm{C}_{2}$ and $\mathrm{C}_{1}$. Maximum biomass produced per unit area was observed in $\mathrm{C}_{3}(60.14 \%$, $22.72 \%$ and $12.21 \%$ more biomass produced then $C_{1}, C_{2}$ and $C_{4}$, respectively) (Table 3). Less biomass production was observed in

Table 2: Physico-chemical parameters of water in the experimental pond

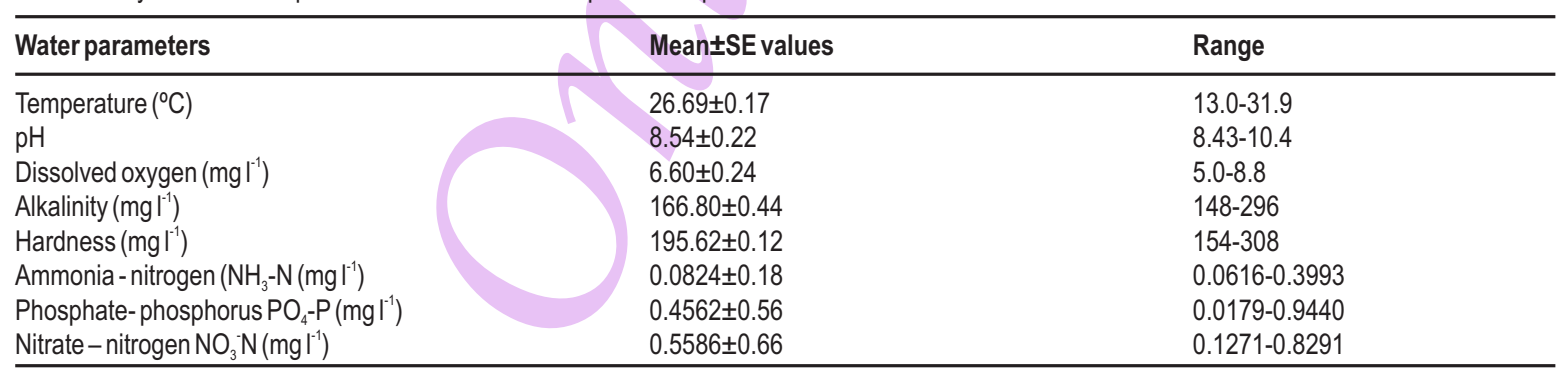

Table 3 : Minimum, maximum growth (length and weight) and biomass produced in different treatments of $P$. pangasius in cages (Initial average length $2.93 \pm 0.2 \mathrm{~cm}$ and wt. $0.25 \pm 0.05 \mathrm{~g}$ )

\begin{tabular}{lllllll}
\hline Treatments & $\begin{array}{l}\text { Final minimum } \\
\text { length }(\mathbf{c m})\end{array}$ & $\begin{array}{l}\text { Final minimum } \\
\text { weight gain }(\mathbf{g})\end{array}$ & $\begin{array}{l}\text { Final maximum } \\
\text { length }(\mathbf{c m})\end{array}$ & $\begin{array}{l}\text { Final maximum } \\
\text { weight gain }(\mathbf{g})\end{array}$ & $\begin{array}{l}\text { Final average } \\
\text { weightgain }(\mathbf{g})\end{array}$ & $\begin{array}{l}\text { Biomass produced } \\
\mathbf{( k g})^{1}\end{array}$ \\
\hline $\mathrm{C}_{1}$ & $22.733 \pm 0.057^{\mathrm{d}}$ & $73.500 \pm 2.50^{\mathrm{b}}$ & $24.333 \pm 0.057^{\mathrm{d}}$ & $79.00 \pm 2.00^{\mathrm{c}}$ & $77.616 \pm 144^{\mathrm{a}}$ & $4.657 \pm 0.144^{\mathrm{a}}$ \\
$\mathrm{C}_{2}$ & $21.400 \pm 0.300^{\mathrm{c}}$ & $72.500 \pm 1.500^{\mathrm{b}}$ & $22.433 \pm 0.152^{\mathrm{c}}$ & $77.333 \pm 0.577^{\mathrm{c}}$ & $75.962 \pm 546^{\mathrm{b}}$ & $6.077 \pm 0.033^{\mathrm{b}}$ \\
$\mathrm{C}_{3}$ & $19.066 \pm 0.057^{\mathrm{b}}$ & $72.333 \pm 0.577^{\mathrm{b}}$ & $21.633 \pm 0.152^{\mathrm{b}}$ & $75.000 \pm 1.000^{\mathrm{b}}$ & $74.580 \pm 776^{\mathrm{d}}$ & $7.458 \pm 0.113^{\mathrm{d}}$ \\
$\mathrm{C}_{4}$ & $16.633 \pm 0.152^{\mathrm{a}}$ & $53.833 \pm 0.288^{\mathrm{a}}$ & $17.633 \pm 0.152^{\mathrm{a}}$ & $56.166 \pm 0.288^{\mathrm{a}}$ & $55.38 \pm 322^{\mathrm{c}}$ & $6.646 \pm 0.132^{\mathrm{c}}$ \\
\hline
\end{tabular}


Table 4 : Growth performance of $P$. pangasius in cages reared at difference stocking densities

\begin{tabular}{lllll}
\hline Treatments & Feed conversion ratio & Daily weight gain $\left(\right.$ g day $\left.^{-1}\right)$ & Relative growth rate $(\%)$ & Protein efficiency ratio \\
\hline $\mathrm{C}_{1}$ & $1.818 \pm 0.007^{\mathrm{c}}$ & $0.647 \pm 0.0005^{\mathrm{d}}$ & $99.78 \pm 0.0007^{\mathrm{c}}$ & $1.825 \pm 0.0007^{\mathrm{b}}$ \\
$\mathrm{C}_{2}$ & $1.646 \pm 0.003^{\mathrm{b}}$ & $0.6285 \pm 0.0013^{\mathrm{c}}$ & $99.77 \pm 0.0010^{\mathrm{b}}$ & $2.026 \pm 0.0010^{\mathrm{c}}$ \\
$\mathrm{C}_{3}$ & $1.548 \pm 0.006^{\mathrm{a}}$ & $0.611 \pm 0.0003^{\mathrm{b}}$ & $99.76 \pm 0.0124^{\mathrm{b}}$ & $2.164 \pm 0.0015^{\mathrm{d}}$ \\
$\mathrm{C}_{4}$ & $1.958 \pm 0.002^{\mathrm{d}}$ & $0.4591 \pm 0.0005^{\mathrm{a}}$ & $99.78 \pm 0.0010^{\mathrm{a}}$ & $1.702 \pm 0.0015^{\mathrm{a}}$ \\
\hline
\end{tabular}

Each value is represented as mean \pm SE; Means followed by same superscript in a column are not significantly different $(p<0.05)$

Table 5 : Length-weight relationship of fish reared in cages

\begin{tabular}{llllllll}
\hline Treatments & $\begin{array}{l}\text { Stocking } \\
\text { density }\left(\mathbf{m}^{-3}\right)\end{array}$ & $\begin{array}{l}\text { Specific growth } \\
\text { rate }\left(\% \text { day }{ }^{-1}\right)\end{array}$ & $\begin{array}{l}\text { Logarithmic equation } \\
\log W=\log \mathbf{a}+\mathbf{b} \log \mathrm{L}\end{array}$ & $\begin{array}{l}\text { Correlation } \\
\text { coefficient }(\mathbf{r})\end{array}$ & $\begin{array}{l}\text { Coefficient of } \\
\text { determination }\left(\mathbf{r}^{2}\right)\end{array}$ & $\begin{array}{l}\text { Condition } \\
\text { factor }(\mathrm{K})\end{array}$ & $\begin{array}{l}\text { Slope } \\
\text { 'b' }\end{array}$ \\
\hline $\mathrm{C}_{1}$ & 15 & 4.729 & $\log \mathrm{W}=\log 0.0103+2.868 \log \mathrm{L}$ & 0.997 & 0.995 & 1.344 & 2.868 \\
$\mathrm{C}_{2}$ & 20 & 4.671 & $\log \mathrm{W}=\log 0.009+2.959 \log \mathrm{L}$ & 0.998 & 0.997 & 1.569 & 2.959 \\
$\mathrm{C}_{3}$ & 25 & 4.658 & $\log \mathrm{W}=\log 0.0089+2.977 \log \mathrm{L}$ & 0.9989 & 0.997 & 1.595 & 2.977 \\
$\mathrm{C}_{4}$ & 30 & 4.438 & $\log \mathrm{W}=\log 0.0083+3.063 \log \mathrm{L}$ & 0.9994 & 0.998 & 1.825 & 3.063 \\
\hline
\end{tabular}
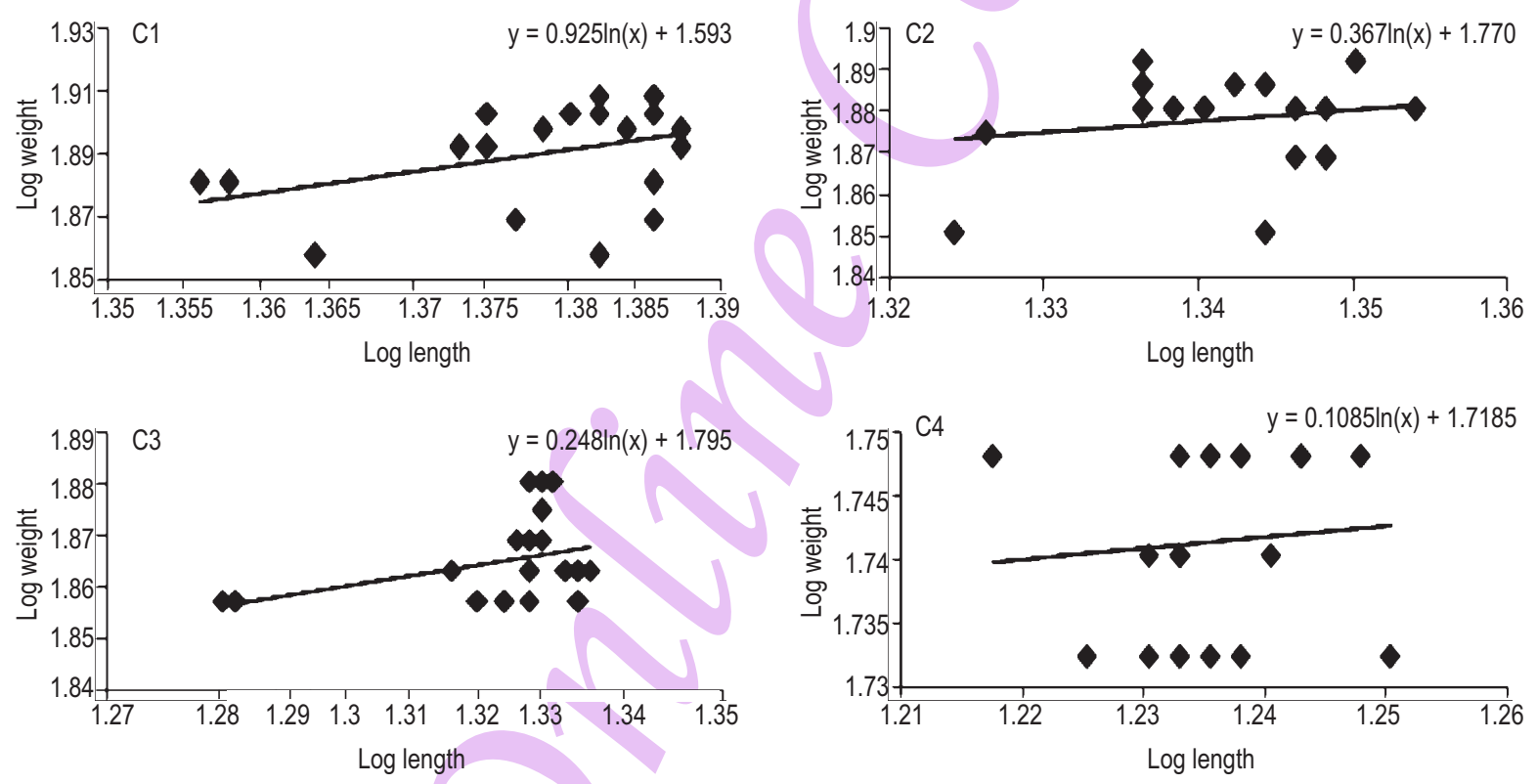

Fig. 1 : Log length and Log weight relationship of Pangasius pangasius in different treatment $\left(C_{1}, C_{2}, C_{3}\right.$ and $\left.C_{4}\right)$

$\mathrm{C}_{4}$ (at stocking density of $30 \mathrm{~m}^{-2}$ ) which might be due to the maximum carrying capacity of unit volume of water reached highest at stocking density of $25 \mathrm{~m}^{-3}$ after the biomass production per unit area had decreased. Fish kept at high densities normally have slow growth (El-Sayed, 2002). Individual growth and population density are known to be closely linked, and the growth of the larger sized fish is dramatically affected by stocking density (Coulibaly et al., 2007).

Significant variation in feed conversion ratio (FCR) was observed among different treatments. Better feed conversion values were noted in $C_{3}(1.541)$ as compared to $C_{1}(1.825), C_{2}$ (1.645) and $C_{4}(1.956)$, indicating higher stocking density having positive relation upto stocking density of $25 \mathrm{~m}^{-3}$, however FCR was decreased afterwards (Table 4). The FCR of Pangasius hypophthalmus was reported in the range of $1: 1$ to $1: 3$ by farmers in India in open pond (Singh and Lakra, 2012). Daily weight gain (DWG) was highest in $\mathrm{C}_{1}(0.6475 \mathrm{~g})$ in comparison to $\mathrm{C}_{2}(0.6296$ g), $C_{3}(0.6113 \mathrm{~g})$, and $C_{4}(0.4596 \mathrm{~g})$, respectively (Table 4). Specific growth rate (SGR) was observed maximum in $\mathrm{C}_{1}$ (4.729) followed by $C_{2}$ (4.671), $C_{3}(4.658)$ and $C_{4}(4.438)$, respectively (Table 5) indicating that DWG and SGR decreased with 
increasing the stocking density. The results are with conformity of the findings of Ali et al. (2005) and Rahman et al. (2006) that DWG and SGR decreased with increasing the stocking density in $P$. sutchi. Length - weight relationship of fish stocked in different cages, values of regression co-efficient ' $b$ ' and logarithmic relationship between length and weight with regression equation are given in Table 5 and Fig. 1. Growth is said to be negative allometric when length increased more than weight $(b<3)$ and positive allometric when $b>3$ (Froese, 2006). When total length was regressed with body weight, final 'b' varied between 2.868 to 3.063. The slope value was significantly lower than critical isometric value i.e., 3 , in three treatments $\left(C_{1}, C_{2}, C_{3}\right)$ indicating negative alometric growth, whereas $\mathrm{C}_{4}$ showed positive allometric growth pattern; thus species become slender with increase in length. The results of the present study is in conformity with the views of Nehemia et al. (2012) that a fish normally does not retain same shape or body outline throughout their lifespan and specific gravity of tissue may not remain constant, the actual relationship may depart significantly from the cube law. Negative allometric growth pattern was observed by Yusof et al. (2011) and Mortuza and Al-Misned (2015). Variation in slope may be attributed to stocking density, carrying capacity and environmental factors (Deka and Gohain, 2015).

Condition factor $(\mathrm{K})$ of a fish reflects physical and biological circumstances and fluctuations by interaction among feeding conditions, parasitic infections and physiological factors (Ndiaye et al., 2015). This also indicates the changes in food reserves and therefore, an indicator of general fish condition. Moreover, body condition provides an alternative to the expensive invitro proximate analyses of tissues (Sutton et al., 2000). Therefore, information on condition factor can be vital for culture system management because they provide the producer with information of the specific condition under which organisms are developing (Araneda et al., 2008). The values of condition factor ' $K$ ' recorded in the present study were 1.344, 1.569, 1.595 and 1.825 in $\mathrm{C}_{1}, \mathrm{C}_{2}, \mathrm{C}_{3}$ and $\mathrm{C}_{4}$, respectively. Condition factor showed well being of fish fed with experimental diet, suggesting that formulated diet was preferred by P. pangasius and digested well. The $K$ value $>1.0$ also indicates that the culture environment and conditions were suitable. Thus, $P$. pangasius is a suitable candidate species for cage culture also. The co-efficient of determination $\left(r^{2}\right)$ values explained proper fit of the model for growth. In the present study, lowest value of $r^{2}$ of $P$. pangasius was recorded as 0.995 (i.e. $99.5 \%$ variability) in $C_{1}$ and highest were recorded as 0.998 ( $99.8 \%$ variability) in $\mathrm{C}_{4}$ (Table 5), indicating more than $99.5 \%$ variability by the model and good fitness.

In the present study, growth rate, condition factor and coefficient of determination value recorded for $P$. pangasius under pond cage culture indicated that maximum biomass can be produced at stocking density of $25 \mathrm{~m}^{-3}$ in a sustainable basis with farm produced feed. Survival rate was recorded constant with different stocking density. The appreciable growth rate exhibited by fish during rearing period indicated that the species is suitable for cage culture at higher stocking density as food fish to meet the increasing nutritional demand of small and marginal farmers with small land holding may adopt these culture technologies for more income generation per unit area.

\section{Acknowledgment}

The authors are grateful to the Indian Council of Agricultural Research (ICAR), New Delhi for funding the project (Niche Area Excellence) and Dean, College of Fisheries, GADVASU, Ludhiana for facilities provided for the study. Authors have materially participated in the research and/or article preparation and authors are declaring no conflict of interest regarding this research article.

\section{References}

Ali, M.Z., M.A. Hossain and M.A. Mazid: Effect of mixed feeding schedules with varying dietary protein levels on the growth of sutchi catfish, Pangasius hypophthalmus (Sauvage) with silver carp, Hypophthalmichthys molitrix (Valenciennes) in ponds. Aquaculture Res., 36, 627-634 (2005).

AOAC: Official methods of analysis. In: Association of official analytical chemists. 18th Edn., Association of analytical communities Press, Gaithersburg (2005).

APHA: Standard methods for examination of water and wastewater. $21^{\text {st }}$ Edn., APHA, AWWA, WPCF, Washington DC, USA (2012).

Araneda, M., E.P. Perez and L.E. Gasca: White shrimp Penaeus vannamei culture in freshwater at three densities: Condition state based on length and weight. Aquaculture, 283, 13-18 (2008).

Bhatnagar, A. and P. Devi: Water quality guidelines for the management of pond fish culture. Int. J. Environ. Sci., 3, 1-30 (2013)

Chattopadhyay, N.R., B. Mazumder and B. Mazumdar: Induced spawning of Pangasius sutchi with pituitary extract. Aquaculture Asia, 7, 43-44 (2002).

Coulibaly, A., I.N. Ouattara, T. Kone, V. N. Douba, J. Snoeks, G.G. Bi and E.P. Kouame'lan: First results of floating cage culture of the African catfish Heterobranchus lonngifilis Valenciennes, 1840: Effect of stocking density on survival and growth rates. Aquaculture, 263, 61-67 (2007).

Datta, S.N., A. Dhawan, S. Kumar, P. Parida and K. Kaur: Comparative economic analysis of pond aquaculture with and without cage. Eco. Env. Cons.,(Supplement) 20, 297-301 (2014).

Deka, P. and A.B. Gohain: Length-Weight relationship and relative condition factor of Rita rita (Hamilton, 1822), Pangasius pangasius (Hamilton, 1822) and Chitala chitala (Hamilton, 1822) of Brahmaputra river system of Assam, India. Int. J. Fish. Aquat. Stud., 3, 162-164 (2015).

Delgado, C.L., N. Wada, M.W. Rosegrant, S. Meijer and M. Ahmed: Fish to 2020: Supply and demand in changing global markets. International Food Policy Research Institute (IFPRI), Washington and World Fish Center, Penang, Malaysia (2003).

El-Sayed, A.: Effects of stocking density and feeding levels on growth and feed conversion efficiency of nile tilapia (Oreochromis niloticus) fry. Aquaculture Res., 33, 621-626 (2002).

Froese, R.: Cube law, condition factor and weight-length relationships: History, meta-analysis and recommendations. J. Appl. Ichthyol., 
22, 241-253(2006)

Halwart, M., D. Soto and J.R. Arthur: Cage aquaculture - Regional reviews and global overview. FAO Fisheries Technical Paper. No. 498. FAO, Rome, pp. 241 (2007).

Htun-Han, M.: The reproductive biology of the dab Limanda limanada (L.) in the North Sea: gonadosomatic index, hepatosomatic index and condition factor. J. Fish Biol., 13, 351-377 (1978).

Hung, L.T., N.A. Tuan and J. Lazard: Effects of frequency and time of feeding on growth and feed utilization in two Asian cat fishes, Pangasius bocourti (Sauvage, 1880) and Pangasius hypophthalmus (Sauvage,1878). J. Aquacult. Trop.,16,171-184 (2001).

Jiwyam, W.: The effect of stocking density on yield, growth and survival of Asian river catfish (Pangasius bocourti Sauvage, 1880) cultured in cages. Aquacult. Int., 19, 987-997 (2011).

Le Cren, E.D.: The length-weight relationships and seasonal cycle in gonad weight and condition in the perch (Perca fluviatilis). J. Animal Ecology, 20, 201-219 (1951).

Mortuza, M.G. and F.A. Al-Misned: Length-Weight relationships of twelve fishes from the river Padma near Rajshahi city, Bangladesh. FishAquac. J., 6, 113 (2015).

Ndiaye, W., D. Khady, S. Ousseynou, P. Ndiaye and J. Panfili: The LengthWeight relationship and condition factor of white grouper (Epinephelus aeneus, Geoffroy Saint Hilaire, 1817) at the south-west coast of Senegal, West Africa. Int. J. Adv. Res., 3, 145-153 (2015).

Nehemia, A., D.M. Justin and C. Rumisha: Length-Weight relationship and condition factor of tilapia species grown in marine and fresh water ponds. Agric. Biol. J. N. Am., 3, 117-124 (2012).

Pal, M.: Pangasius pangasius. IUCN Red List of Threatened Species. Version 2014.1. International Union for Conservation of Nature. Retrieved 14 July 2014 (2010).

Pillay, T.V.R. and N.K. Kutty: Aquaculture principles practices. $2^{\text {nd }}$ Edn., Blackwell Publishing, London, p. 640 (2005).

Rahman, M.M., M.S. Islam, G.C. Halder and M. Tanaka: Cage culture of sutchi catfish, Pangasius sutchi (Fowler 1937): Effects of stocking density on growth, survival, yield and farm portability. Aquaculture Res., 37, 33-39 (2006).

Singh, A.K. and W.S. Lakra: Culture of Pangasianodon hypophthalmus into India: Impacts and present scenario. Pakistan J. Biol. Sci., 15, 19-26 (2012).

Snedecor, G.W. and W.G. Cochran: Statistical methods. Oxford and IBH Publishing Co., New Delhi, p. 135 (1967).

Sokal, R.R. and F.J. Rohlf: Introduction to biostatistics. $2^{\text {nd }}$ Edn., Freeman Publication, New York, pp. 132-136 (1987).

Sutton, S.G., T.P. Bult and R.L. Haedrich: Relationships among fat weight, body weight, water weight and condition factors in wild Atlantic salmon parr. Trans. Am. Fisheries Soc., 129, 527-538 (2000).

Yi, Y. and C.K. Lin: Effects of biomass of caged Nile tilapia (Oreochromis niloticus) and aeration on Nile tilapia (Oreochromis niloticus) and aeration on pond system. Aquaculture., 195, 253-267 (2001).

Yusof, M.F., S.S. Siraj and S.K. Daud: Length-weight relationships of seven catfish species in Peninsular Malaysia. J. Fish. Aquat. Sci., 6, 828-833 (2011) 